$\stackrel{N / 2}{N}$

Global Journals Inc

(2)

\title{
The Psychological Factors that Founder Need to Build and Develop a Digital Startup
}

\author{
By Agnes Dessyana \& Prof. Dr. Benedicta Prihatin Dwi Riyanti \\ Magister Psikologi Profesi Universitas Katolik Indonesia Atma Jaya
}

Abstract- This study was alligned with the research about significant role from entrepreneurial self-efficacy (ESE) and innovation to digital startup success (Dessyana \& Riyanti, 2017). Those study showed an interesting result from multiple-regression analyses that reveal ESE and innovation contributes $20.8 \%$ to business success with ESE regression coefficient is $0.200(P<0.05)$ and the innovation of $0.026(p>$ 0.05). This means there is a positive relationship and significant role from ESE on business success, while innovation has a positive relationship but insignificant.

Meanwhile, in this study, researchers would focused to explore about psychological factor that founder need to build and develop digital startup. Researchers was using mix method approach. Questionnaire about ESE, innovation, and startup success already distributed to 64 founders at previous study. Next, interviews were conducted to know more about what and how a psychological factors shown. The sample was three startup communities and member's communities who have an appropriate criteria.

Researcher was found six factors: (1) The importance of detail blueprint and clear vision, (2) The prestige of a right circle to find a right co-founder, (3) Have positive intention to help people solve the problem, (4) Continous innovation to enlarge company, (5) Self-efficacy, and (6) Support from family and friend.

Keywords: technopreneurship, entrepreneurial self-efficacy (ESE), innovation, business success, digital startup.

GJMBR-A Classification: JEL Code: M13

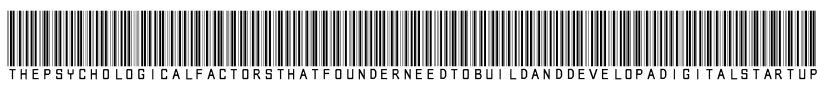

Strictly as per the compliance and regulations of:

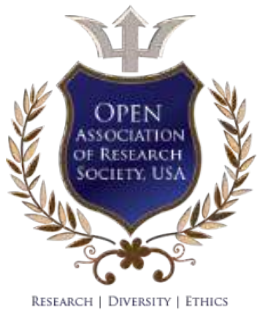

(C) 2019. Agnes Dessyana \& Prof. Dr. Benedicta Prihatin Dwi Riyanti. This is a research/review paper, distributed under the terms of the Creative Commons Attribution-Noncommercial 3.0 Unported License http://creativecommons.org/licenses/by-nc/3.0/), permitting all non-commercial use, distribution, and reproduction in any medium, provided the original work is properly cited. 


\title{
The Psychological Factors that Founder Need to Build and Develop a Digital Startup
}

\author{
Agnes Dessyana ${ }^{\alpha} \&$ Prof. Dr. Benedicta Prihatin Dwi Riyanti ${ }^{\sigma}$
}

\begin{abstract}
This study was alligned with the research about significant role from entrepreneurial self-efficacy (ESE) and innovation to digital startup success (Dessyana \& Riyanti, 2017). Those study showed an interesting result from multipleregression analyses that reveal ESE and innovation contributes $20.8 \%$ to business success with ESE regression coefficient is $0.200(P<0.05)$ and the innovation of $0.026(p>$ 0.05 ). This means there is a positive relationship and significant role from ESE on business success, while innovation has a positive relationship but insignificant.

Meanwhile, in this study, researchers would focused to explore about psychological factor that founder need to build and develop digital startup. Researchers was using mix method approach. Questionnaire about ESE, innovation, and startup success already distributed to 64 founders at previous study. Next, interviews were conducted to know more about what and how a psychological factors shown. The sample was three startup communities and member's communities who have an appropriate criteria.

Researcher was found six factors: (1) The importance of detail blueprint and clear vision, (2) The prestige of a right circle to find a right co-founder, (3) Have positive intention to help people solve the problem, (4) Continous innovation to enlarge company, (5) Self-efficacy, and (6) Support from family and friend. Those results showed three of six factors was a psychological factor, while another three was personal factor and social factor. Those result aligned with the previous study from Zaheer (2015) that mentions four of six factors contribute the successful of digital startup.
\end{abstract}

Keywords: technopreneurship, entrepreneurial selfefficacy (ESE), innovation, business success, digital startup.

\section{INTRODUCTION}

T oday, digital industry in Indonesia is growing. The growth of the digital industry is characterized by an emergence of startup digital companies. The interesting point is young generation playing the important role. Majority of the founder of startup digital companies are youth people who have an age range between $20-35$. There is many factors that encourage that phenomenon, such as the inspiration from aboard success, the support from Indonesia government, active internet user from digital age, and the acquisition of local startup by Yahoo Corporation (Arjanti \& Mosal, 2012). Today at 2019, Indonesia Government also want to create a digital ecosystem with their 1000 digital

Author a: M. Psi, Psikolog, Magister Psikologi Profesi Universitas Katolik Indonesia Atma Jaya. e-mail: agnes.dessy@gmail.com

Author o: M. Psi, Magister Psikologi Profesi Universitas Katolik Indonesia Atma Jaya. e-mail: benedictariyanti@yahoo.com startup program that increasing an interest of young generation to become founder ("Mengapa Startup", 09 Sept 2016).

Still, it is not an easy choice to become an entrepreneur in Indonesia. There are various aspects to be considered in developing a company, especially startup digital. In general, the intention to build a startup comes from an idealist vision to solve the social problem. In the study related to the success and entrepeneur, there are many factors that contribute to build a great startup. Zaheer (2015) mentions the factors is background of the founder (i.e. education and experience), motivation and commitment founder to expand the business, founder personality, innovation and creativity, as well as external factors (i.e. relations and environment). Yet, there is a few studies in Indonesia that explain what is the psychological factors that founder need to build a digital startup. Even though, the individual factors in founder can become a determinant role to build startup. The founder has an important role because founder who is a person who create a vision and mission, the organizational structures, and also the long term development plan for their digital business. It is because the founder has a role as the creator, owner, and management of digital startup.

Based on psychological research (Fini, et. Al, 2009), characteristic and personality related to intention to become entrepreneur. Similar with those study, some of those personalities factor also have a significant relationship with the success of the business, such as the need for achievement, self-efficacy, innovation, proactive, confident, resilient to stress, and the need for independent (Rauch and Frese, 2007; Tagraf and Akin, 2009). One of the most important concepts to be seen is self-efficacy. According to Bandura (2010), self-efficacy is the belief in the individual ability to perform a task or action to achieve certain goals. Someone who has a high self-efficacy will tend to work harder and more persistent to face an obstacles and find a way out of the difficulties to accomplish success. This makes people more likely to achieve their goals. The research about entrepreneurial self-efficacy has talked about how selfefficacy can influence entrepreneurial intentions where the higher the value of self-efficacy, the higher the desire for self-employment (Batubara \& Tamaria, 2016).

The association between self-efficacy and business success has an important meaning. The 
higher individual belief in conducting business activities will be affect the behavior of individual business development. The more a person has belief about his ability to run a business then the greater the effect on the individual business development (Drnovsek, Wincent, \& Cardon, 2010). This concept known as an entrepreneurial self-efficacy/ESE.

Besides those factors, it is also important to discuss the concept of innovation. It is because they need innovation as a tool to execute their creative ideas on startup digital. Aligned with the research that conducted by Rauch and Frese, four psychology students from the University of London conducted another study related to the relationship between the personality traits of the Big Five model to predict business success. From this study found narrow personality traits, namely innovativeness predicts business success better than broad traits, such as conscientiousness and extraversion (Leutner, Ahmetoglu, Akhtar, \& Premuzic, 2014). In psychology, individual innovation can also be seen from the way or process of thinking. With this concept, we can see how the creative thinking give an influence to build a concept of their startup. Kirton innovation theory will be used to see innovation from the perspective of personality. Kirton believes that there are three elements that differentiate the style of a creative person, namely originality, efficiency, and group-conforming. All three of these elements will determine whether a person is an adaptor or innovator (Kirton in Riyanti, 2003).

In the entrepreneurial process, creating and developing a business isn't an easy task. Factors, such as an uncertainty condition, obstacle, and responsibility to develop will determined someone to become an entrepreneur or not. One of interesting facts within this digital startup is the role of community or group. Today, Indonesia have many community about entrepreneural, especially about technopreneurship. In those community, the members have a similar passion to build a startup digital and encouraged to support each other. The community often held an events, i.e. gathering or seminar, to share and discuss updated information about digital startup. That efforts makes the community bigger and attract people to join the community.

In this study, another unique characteristics from digital startup is innovation should be combined with the skills or ability to use technology. This also the reason for the establishment of digital startup communities. Giving knowledge, share experiences and tips about develop startup digital make founders and members of the community to belief that they can do this business.

This study was alligned with the research about significant role from entrepreneurial self-efficacy (ESE) and innovation to digital startup success (Dessyana \& Riyanti, 2017). Those study was focused to know about an influence of innovation and ESE to digital startup success. Now, researchers will be more focused to explore more about a psychology factors that founder need to build and develop digital startup. So, we will get a better understanding about digital startup success.

\section{a) Research Question}

1. What is psychological factors that people need to build and develop a digital startup?

2. How does innovation and entrepreneurial selfefficacy factors in supporting people to build and develop digital startup?

\section{Literature Review}

This segment offers the synopsis of related literature. It will be divided to three part. First is about a startup lifecycle to know a context overview about startup. Second, it's about factors that influence people to become entrepreneur. The third is about factors that are critical to measure startup success.

a) Startup Lifecycle

Based on the results of Startup Genome Report (2012), there are four stages of development that are passed by a startup, namely:

\begin{tabular}{|l|l|l|l|}
\hline \multicolumn{1}{|c|}{ Stage } & \multicolumn{1}{|c|}{ Focused } & \multicolumn{1}{c|}{ Challenged } & Enterprise Age \\
\hline Discovery & $\begin{array}{l}\text { Create and build an idea } \\
\text { that can provide added } \\
\text { value or solve problems } \\
\text { for customers or users. }\end{array}$ & $\begin{array}{l}\text { - decide the added value and } \\
\text { initial products } \\
\text { - finding a team } \\
\text { - searching for investor, } \\
\text { incubation, or acceleration }\end{array}$ & $3-7$ months \\
\hline Validation & $\begin{array}{l}\text { Seek an approval that } \\
\text { users / communities are } \\
\text { willing to use their } \\
\text { services or products. }\end{array}$ & $\begin{array}{l}\text { - Find market opportunities } \\
\text { - Repeat service usage / product } \\
\text { purchases } \\
\text { - Achieve a desired growth }\end{array}$ & $8-13$ months \\
\hline
\end{tabular}




\begin{tabular}{|l|l|l|l|}
\hline Efficiency & $\begin{array}{l}\text { Make an adjustment } \\
\text { between the added value } \\
\text { and the financial condition } \\
\text { of the company. }\end{array}$ & $\begin{array}{l}\text { - How to fundraising } \\
\text { - Maintain a great solid team } \\
\text { player } \\
\text { - Achieve customer expectations } \\
\text { \& having loyal customers }\end{array}$ & $14-20$ months \\
\hline Scaling & $\begin{array}{l}\text { Accelerate customer } \\
\text { growth, income, or both. } \\
\text { This stage lasts for about } \\
\text { 7-9 months and is the most } \\
\text { important stage and } \\
\text { determines whether a } \\
\text { startup will growing or } \\
\text { failing. }\end{array}$ & $\begin{array}{l}\text { - Adjust growth with } \\
\text { organizations } \\
\text { - Forming a necessary } \\
\text { department } \\
\text { - Fundraising. }\end{array}$ & > 20 months \\
\hline
\end{tabular}

In this study, we will look at the startup's stage to know more about characteristics and also a business model from each startup.

\section{b) Factors to become an entrepreneur}

There are some factors that influence people to become entrepreneur (Kinggudu, 2002; Ullah, et al, 2012; Sowole, et al, 2018), such as:

1. Demographic factors: age, gender, social status, education, experience, and ethnicity

2. Psychological factors: courage to take risks, need of achievement, self-efficacy, self-confidence, autonomy, internal locus of control, motivation, entrepreneurial spirit, creative, innovation, and intention to act

3. Skills: technical expertise, managerial expertise, personal relationship skills, business acumen, marketing expertise, and innovation

4. External factors: government policies, socioeconomic and political state, infrastructure conditions, and the country's economic system.

In this study, researchers want to know what is factors that people need to become a founder then build and develop a digital startup.

c) Factor that are critical to measure startup success

A study conducted in the United States by the Startup Genome Project (2012), describes five factors that must be develop to become a critical key as a startup success, namely:

1. Consumers

Key metrics: number of consumers, percentage of users who can be said as a loyal.

2. Products

Product must be clear, precise, and needed by consumers.

3. Team

Team must be solid and have the same vision.

\section{Financial}

Have a great view about cost structure and revenue model of startup company.

5. Business model

A clear and systematic business model is one of the things that needs for startup.

\section{ili. MeTHOD}

\section{a) Research Method and Population}

Researchers used mixed method explanatory sequential analysis, where quantitative methods used first, then followed by qualitative methods with the aim to provide an explanation and interpretation of the quantitative results that previously obtained.

For quantitave methods, researchers used the data that already obtained, which is a questionnaire consist of demographic, statup characteristic, entrepreneural self efficacy (ESE) and innovation KAl. Those data was processed using descriptive statistical technique. For qualitative method, researcher used the data from interview to completed and explained about the quantitative data. Respondents must have this characteristic: (1) the owner of startup digital, such as creator websites, creator applications, games developer, software developer, and so on; (2) have started businesses approximately 3 months; (3) is part of the initial founder (part of team founder); (4) the members of startup community.

Total population is unknown so to determine the sample for quantitative method, researcher use the following criteria: (a) a decent sample size in the study were between 30 to 500; and (b) If the research will perform with multivariate analysis (i.e. correlation or multiple regression), then the number of sample members at least 10 times the number of variables studied. For example there are five research variables (independent + dependent), the number of members of the sample $=10 \times 5=50$ (Roscoe in Sugiyono, 2010). The sampling technique is the nonrandom sampling, 
namely convenience sampling. Total number of samples obtained for quantitave method is 64 founders.

Meanwhile, for qualitative method, basically there are no certainty regarding the number of respondents, because the research focuses more on the depth of data. Considering about the amount of time and availability of respondent, the interviewed was conducted to three people.

\section{b) Questionnaire Tools}

There are two variables in this study that researchers want to measure using a quantitative method, which is is innovation and entrepreneurial selfefficacy. The innovation behavior is the tendency of innovation to be innovative or adaptive. It will be measured by KAl instrument (Kirton AdaptionInnovation). There are three dimensions, namely originality idea, efficiency, and group conforming). In KAI there are 31 statements and measured using a Likert scale of 1 to 6 . The higher score indicates a tendency to act more innovative (innovative creative), the lower score indicates a tendency to act adaptive (adaptive creative).

Meanwhile, entrepreneural self-efficacy is the belief of the individual toward his ability in conducting entrepreneurship to achieve a success. It will be measured by ESE instrument. There are six components in the concept of ESE (Barbosa, et al., 2007). In ESE there are 24 statements and measured using a Likert scale of 1 to 6 . The higher score indicates a tendency of respondents have high levels of self-efficacy, and vice versa. The lower the score, show respondents have low levels of self-efficacy.

\section{c) Interview Tools}

The method for qualitative is unstructured interviewed guidance of interview to explore about startup lifecycle and factors that founder need to build and develop their startup. Researcher used an openended question to know more about startup success, such as financial and consumer. Researcher also create a question to know about their history, reason to build startup, vision and mission, also their life experience that they need to build and develop startup. Some of example:

1. What is your reason to build this startup?

2. What do you expect from this startup?

3. How much time you need to build this startup?

4. From your perspective, what is the important factor that help you believe that your startup will be success in future?

\section{Result}

a) Respondent Demographic Data

\section{DEMOGRAPHIC DATA (GENDER)}

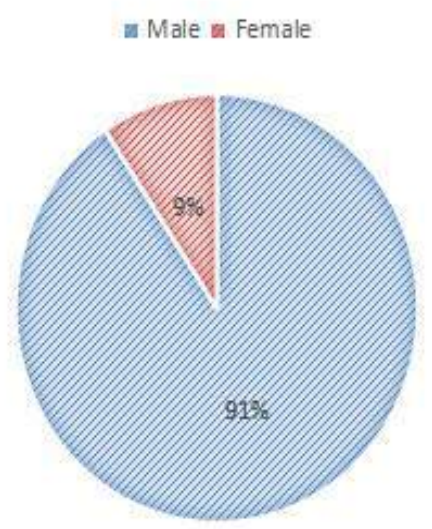

Chart 1: Demographic Data (Gender) 


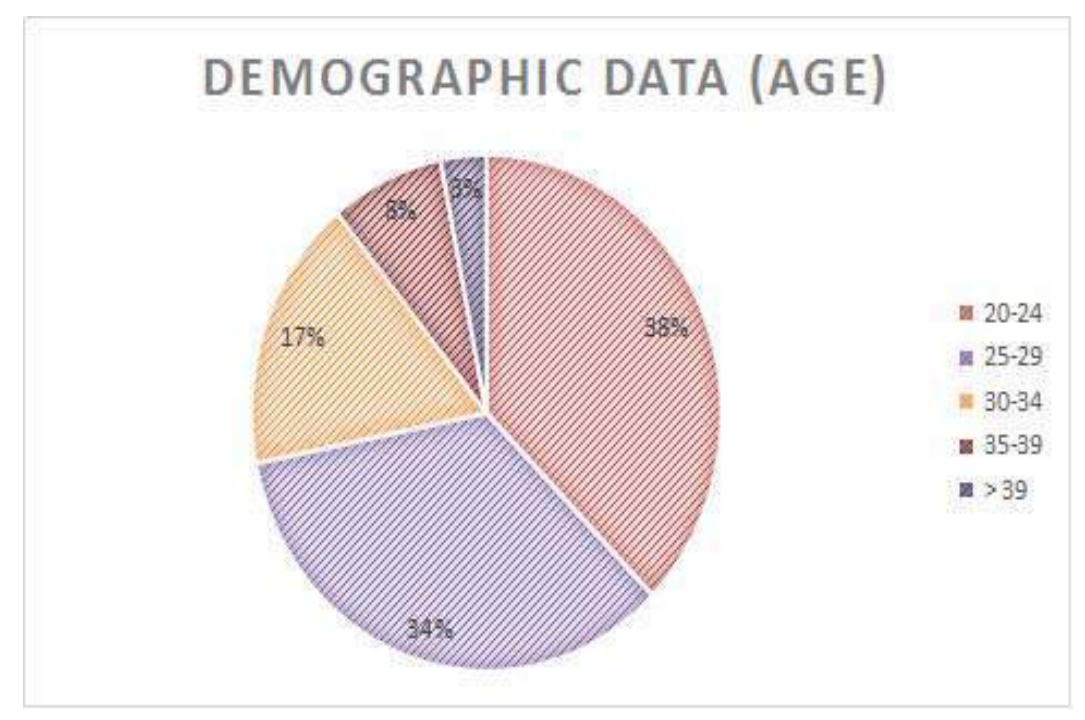

Chart 2: Demographic Data (Age)

Respondents consisted of 58 (86.6\%) male and 6 (9\%) women, aged between 20-39 years old. Based on generation theory, this group age included in the Generation $Y$ and $Z$. Character distribution of generations based on birth span. This is to explain that the characteristics of the founder is a generation who are familiar with the internet. They have been exposed to digital technology and often use it in everyday life (Jones \& Shao, 2011; Sivalingan \& George, 2011). This causes them to be more open to the use of technology and more eloquent to use the technology in their lives.

b) Descriptive Statistic

The following will explain the descriptive data from this research.

Table 1: Descriptive Overview

\begin{tabular}{cccc}
\hline Instrument & Mean & $\begin{array}{c}\text { Standard } \\
\text { Deviation }\end{array}$ & Range of Data \\
\hline KAI & 137,52 & 24,71 & $31-175$ \\
\hline ESE & 119,88 & 15,45 & $48-143$ \\
\hline
\end{tabular}

Range score innovations have score of 31 to 175 with an average 137.52. It shows that the innovation score of founders is moderate. It means, founders prefer to use the style of thinking Bridger, combination of innovative and adaptive. It is not much different from additional data obtained by researchers where more innovative style of creative thinking was applied to find an ideas and find the problems that exist in the field. However, later in the execution of the idea and the process of change, the digital startup owners are more likely to use a gradual change and are looking for ways that are already used by the mentors or experts who are experienced and then apply it to the business they run.

Range score ESE for founder digital startup are in range of a score 48 up to 143 with an average 119.88. It shows that scores on ESE is moderate. This means that overall the digital startup founders have the ordinary belief on their ability or skills to manage and develop startup. This suggests that the skills they have match to what is required in creating and managing their business.

\section{c) Qualitative Analysis}

The following will present information about the startup interviewed. Researcher interviewed respondent with an appropriate characteristics, such as : (1) have a high or medium score of ESE; (2) have a high or medium score of innovation; (3) lived in Jabodetabek; (4) active in startup community; (5) part of a founder team (or co-founder). 


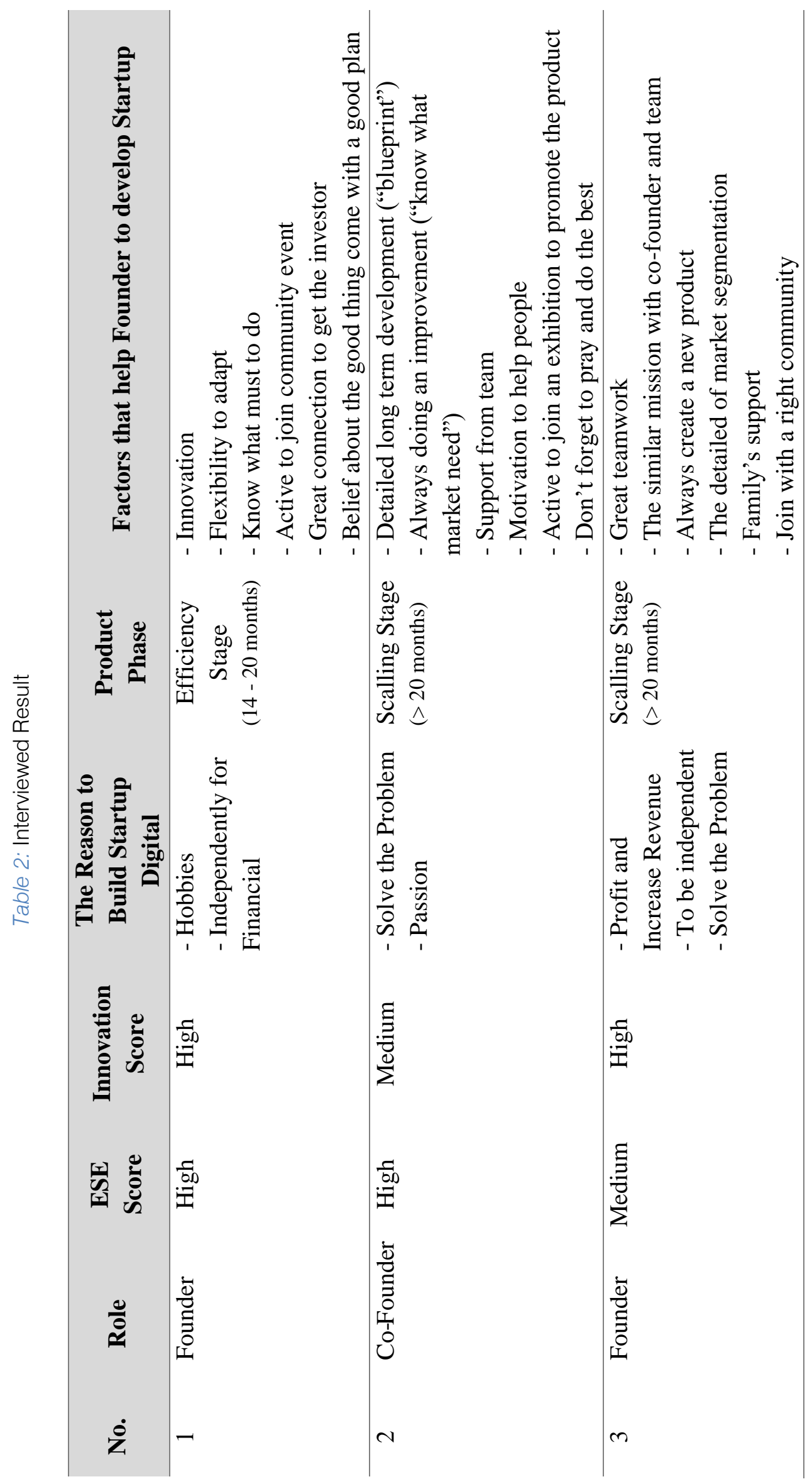


The founder who run their business with high self efficacy have a tendency to be more adventurous and eager to face the challenges. This is also make them want to trying new things than those who had lower score of self-efficacy. High self efficacy helps them to be better prepared in the face of obstacles, interact with investors, employee development, and create products in achieving success.

Based on this interviewed, there is some reason to build a startup, such as motivation to solve the problem, want to have a financial independent, and also a passion to help people. The age of the business is in the range of 14 months to 2 years, the development preferably to keep/maintain products, application/ website, and consumer. In doing the maintenance, founders prefer to find ways and strategies that have been successful allign with their mission and long term development plan ("blueprint"). Moreover, they have a community that is active and support each other by sharing knowledge and new information about exhibition. Community also a place for founder to get more connection and find a partner or solid team who have a similar passion. The support from friend, family, and investor, also become a point to become success to create a digital startup.

Based on interview conducted by researcher in this study, it's interesting to find that the concept 'does not give up' who spoken by the founder is often associated with the belief and trust to become more confident. The founders pointed out that they need the belief to be confidence, either to build the startup or taking a decicion making to choose a good opportunity for their business (Interview on 16-17 November 2016). Therefore, the concept of self efficacy and community becomes appropriate to related it of founder for startup digital. This is similar to the result of research from Wood, et al (in Punnet, et al., 2007), who stated about self-efficacy that has been proven to predict the effectiveness of using strategies in making managerial decisions.

In interview, founders also said that innovation is necessary to create and develop the product to solve problem. Innovation is also important when they need new method to grow their business and attract people to get to know their product. Moreover, innovation is becoming a strategy to determine how they build the blueprint, improve technology, and enhance a startup system.

Based on the results of interviews with, it also found that when setting up a digital startup, the founders did not work alone. Usually, founders will work together with co-founders (partners), or form a team of $4-5$ people in setting up and running a digital startup business. The team formed consists of individuals who have a similar vision, namely to create a digital-based application that can help solve a problem and have the spirit not to give up. In addition, team members usually consist of young people who are more fluent and open to technology. The founder's educational background is usually between information technology, management, or communication science (Interview on 24 November 2016).

When asked about solving the problem, founders always have a mission to help people. One of the founder told his story about their blueprint. He was named Brother $\mathrm{T}$, one of the founders of a digital startup business, which is engaged in online language learning media. His business was built in early 2015 and has been running for almost two years. He had a purpose to create an online learning that help people easier and more enjoy to learn languages (especially English) so that everyone can learn easily, quickly, and pleasantly. Brother $\mathrm{T}$, who has a background in information technology, formed a team that have a similar passion to help him build and develop his business on various learning platforms (websites, android smartphones, and iOS). According to him, one of the things that is the key to the success of the release of this online learning platform is because of a solid team, innovation, a clear vision, know what market need, his educational background, an experience doing business projects, and also a support from family and friend (Interview on o1 October 2016).

Based on those interviews results, researcher then categorize those data to six factors to know about what is the factors help people to build and develop digital startup: (1) The importance of detail blueprint and clear vision, (2) The prestige of a right circle to find a right co-founder, (3) Have positive intention to help people solve the problem, (4) Continous innovation to enlarge company, (5) Self-efficacy, and (6) Support from family and friend. Those results showed three of six factors was a psychological factor, such as (a) positive intention, innovation, and self efficacy. Those result aligned with the previous study that stated psychological aspect have a positive effect to entrepreneurial success (Przepiorka, 2017). This research also has another interesting result which find that another three factors that contribute to value of founder categorized of personal factor and social factor. Those aligned with the previous study from Zaheer (2015) that mentions four of six factors contribute the successful of digital startup.

\section{Conclusion}

This study aimed to know the psychological factors that people need to build and develop digital startup. The findings of this study indicate that in the context of startup ventures, psychological characteristics have a tendency to dominate a person to become success. The important psychological characteristic that influence an entrepreneurial behavior (startup development) is an entrepreneurial self-efficacy, 
innovation, and positive intetnion to help people or solve problem. Those characteristic will give them a intention and motivation to build a good startup and develop their business to become success. In this case, researchers also found that the concept of ESE becomes important, because when the founder did not have the strong believe of their ability to develop startup, they are less actively involved in community activities

Otherwise, the founders who believe in their ability will become more active and participate in various activities aimed at enhancing cooperation, increase knowledge, or to make a development on the business. Meanwhile, innovation plays a role only in the initial stage as in the development stage in the startup phase (3 months - 2 years). In this stage, the founder tends to increase the knowledge than to use the style of thinking innovation. And, the most important thing is to have a positive intention to build a startup to help solving the problem. Because, it will make the founder to have a clear goal, detailed vision, and create a alligned long term development for their business. It is also gives them the tendency to join the community and find a copartner or team who will help them to develop their business.

\section{Vi. Discussions and Recommendations}

The founders who have faith in their skills and abilities to manage the business and develop startup, will have more intention to build startup and become more success with their business. This is alligned with research conducted by Inggarwati and Kaudin (2010) which states that when entrepreneurs have high self efficacy, will have a higher desire to develop the business than the one who has low self efficacy. A similar result was found in research conducted by Herath \& Mahmood (2014) which states that existence of higher level self-efficacy among entrepreneurs will be helpful for them to improve the performance of their behavior to develop new product, prepare a plan to adjust with unexpected challenge, and developing their team. Having a higher entrepreneurial self-efficacy make founder more confident to facing uncertainty of the business environment so that more had the desire and the courage to build and develop the business.

Innovation also become as one of factor to predict the founder to build and become successful at their business. This is in line with a study was conducted by Rauch and Frese (2007), that mention about innovation was used as a factor that will be the determinant of how employers implement creative ideas in the formation and implementation of business ideas.

In addition, another thing that should be considered in conducting research on digital startup is to notice the proximity and collaboration between founder. This can been seen from their relationship between founder, co-founder, and team. This is also can been seen within the proximity between member of startup community. They have a tendency to join a community who have a similar passion, and they can be so open with each other even to share information, knowledge, investor, or experience so they can help each other in running their digital startup. It will be very interesting to see how the cultural climate of the digital startup community and connection with business development digital startup itself.

Although, the sample in this study is small and comes from various fields and business models of business startup and the amount is not too balanced to cover for each category of its business model. This may affect the kind of factors that will appear to build and develop digital startup. Therefore, perhaps in future research, it can be focused on a particular business model or are looking for a balanced number of samples for each category.

\section{Vil. Intervention Overview}

To develop a startup business, founders as an owner and CEO, must have the broad knowledge about managing business, technological knowledge, and also marketing digital. The unique thing about digital startup, founder was too focused on the aspect of technology. Sometimes they forget to improve their skill for managing business, such as manage financial aspect, how to create a firm business process, develop an interpersonal skill to attract the investor and co-founder, etc.

The intervention was carried out by providing information about the importance of the business plan and direct customer analysis. With some help from website developer, the researcher creates a website platform who provide the knowledge for create and develop a digital startup business.

\section{Blueprint of intervention:}

1. Media Intervention: Website Platform

2. Name of website: https://yukusaha.com/elearning/

3. Purpose: YUK USAHA is developing a learning platform program for college students who want to become founder, because nowadays they don't know why they must choose to become an entrepreneur and how to develop business, by featuring educational path program, personality and competency profiling, and book report. 
4. Model platform
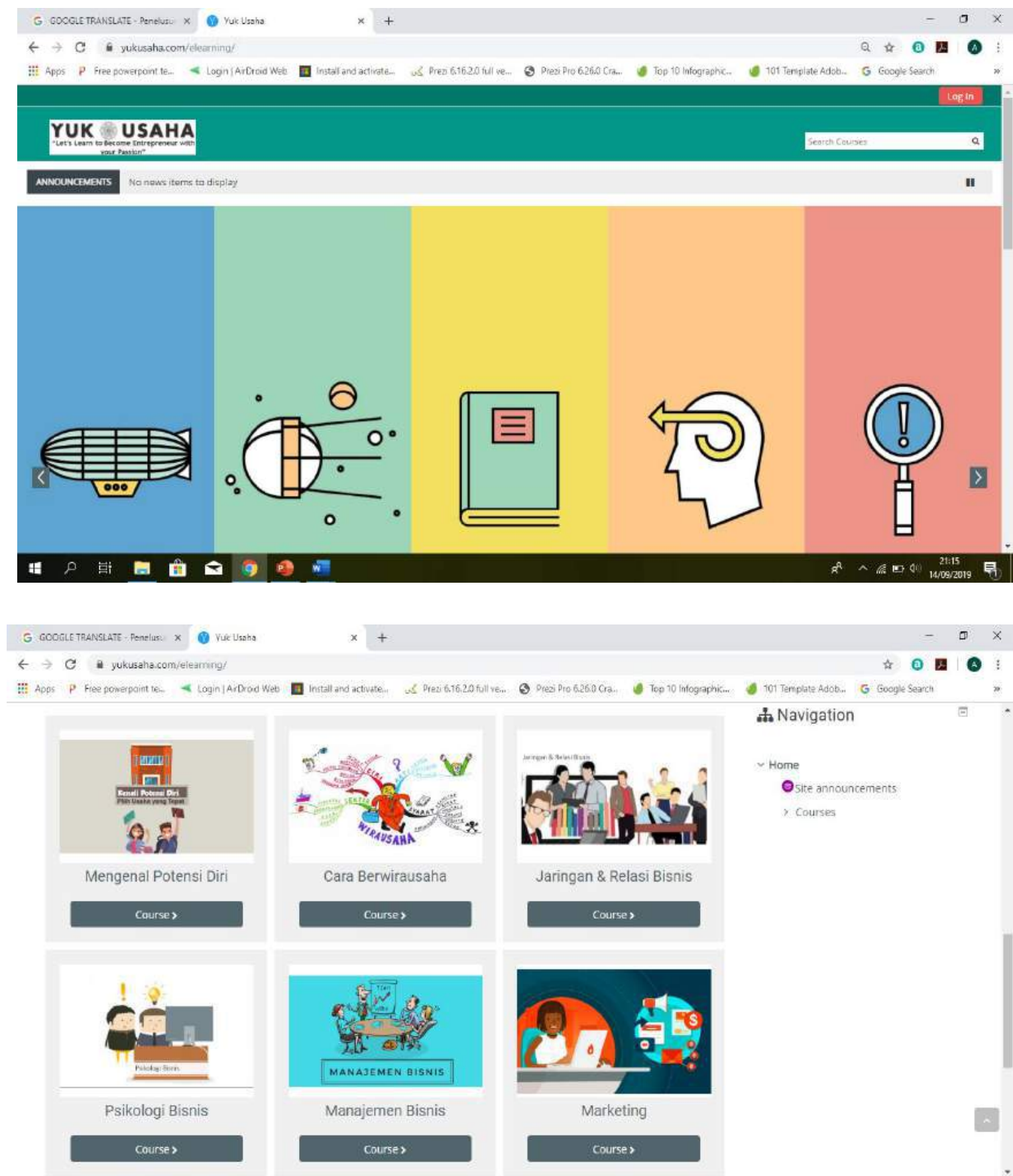

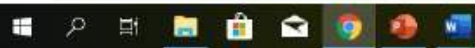

5. Overview agenda of intervention plan.

- First: Create a curriculum path and syllabus of digital business education for founder at August 2019 until September 2019.

- Second: Socialize the prototype of platform at October 2019 until November 2019.

- Third: Evaluation until December 2019.

- Fourth: Improving the platform based on the result of evaluation.

\section{Vili. Managerial Implication}

Psychological factors that help founder to build and develop digital startup, are entrepreneural selfefficacy (ESE), innovation, and posisitve intention to solve the problem. Therefore, efforts to encourage business development do not have a strong impact if the founder does not have those characteristics. The implications of this study are: 
1. For institutions or communities who want to develop a digital startup business in Indonesia, should consider providing curriculum to enhance those characteristic and know how psychological factors play an important role to build and develop digital startup. Provision of knowledge and skills are made in the form of seminars, workshops, or bootcamps. Hopefully, community or institution can create a bootcamp to build those characteristics and give a founder a boost to have a great confindence, enhance their innovation, and also have a social mission to become a problem solver of the social problem within their area.

2. Institutions and communities also need to actively and regularly conduct meetings of founders, such as exhibition, gathering, and bazaar. These meetings to build relationships and connections as one way to increase success in the digital startup business (Nann, et al, 2009). These meetings can also help founders who have similar businesses to learn from each other and share information related to how to build and develop their digital startup.

3. The institution and community should also start thinking about how to improve innovative and creative thinking skills for the founders. With innovation, the founder will be able to apply creative ideas in developing his business. This is what will be needed to make digital startup continuously in the creative and technological industries, which are very fast changing, unpredictable, and competitive (York \& Danes, 2014; Carlson \& Usher, 2015).

\section{References Références Referencias}

1. Arjanti, R. A. \& Mosal, R. L. 2012. Startup Indonesia: Inspirasi dan pelajaran dari para pendiri bisnis digital. Kompas Penerbit Buku, Jakarta.

2. Bandura, A. 2010. Bandura's instrument teacher self-efficacy scale. Sage Publisher, New York.

3. Barbosa, S.D., Gerhardt, M.G. \& Kickul, J.R. 2007. The role of cognitive style and risk preference on entrepreneurial self efficacy and entrepreneurial intentions. Journal of Leadership and Organizational Studies. 13(4): 87-104.

4. Batubara \& Tamaria, A. 2016. Pengaruh Efikasi Diri dan Kompetensi Kewirausahaan terhadap Minat Berusaha pada Siswa/l SMK Negeri 10 Medan. Skripsi Sarjana, tidak diterbitkan. Universitas Sumatra Utara, Medan.

5. Brandstatter, H. 2010. Personality Aspects of Entrepreneurship: A look at five meta-analysis. Journal of Personality and Individual Differences. 10(2): $1-9$

6. Britania, B. \& Anggono, A. H. 2014. Analyzing the Factors Affecting Business Performance of Startup
Companies in Digital Creative Industry in Indonesia. Journal of Business Strategy and Social Sciences. 1: $566-576$

7. Carlson, M. \& Usher, N. 2015. News Startups as Agents of Innovation. Digital Journalism. 4(5): 563-581.

8. Chen, C. C., Greene, P.G., \& Crick, A. 1998. Does entrepreneurial self-efficacy distinguish entrepreneurs from managers. Journal of Business Venturing. 13: 295-316.

9. Creswell, J. W.; Clark, V.L.P. (2007). Designing and conducting: mixed methods research. London: SAGE Publications.

10. Crocker, L \& Algina, J. 1986. Introduction to Classical and Modern Test Theory. Wadsworth Group, USA.

11. Dessyana, A. \& Riyanti, B. P. D. 2017. The Influence of Innovation and Entrepreneurial Self-Efficacy to Digital Startup Success. International Research Journal of Business Studies. 10 (1): $57-68$.

12. DetikNews. 09 September 2016. Mengapa Startup Digital Menjamur di Indonesia dan Apa Keuntungannya. Downloaded from: https://news. detik.com/adv-nhl-detikcom/d-3294522/mengapastartup-digital-menjamur-di-indonesia-dan-apakeuntungannya

13. Drnovsek, M., Wincent, J., \& Cardon, M. S. 2010. Entrepreneurial Self-Efficacy and Businness Startup: Deeloping a multi-dimensional definition. International Journal of Entrepreneurial Behaviour \& Research. 16(4): 329-348.

14. Fini, R., Grimaldi., R, Marzocchi, G., \& Sobrero, M. 2009. The Foundation of Entrepreneurial Intention. Research Gate. 1 - 48.

15. Herath, H. M. A. \& Mahmood, R. 2014. Dimensions of Entrepreneurial Self-Efficicacy and Firm Performance. Global Journal of Management and Bussiness Research. 14(4): 22-30.

16. Inggarwati, K. \& Kaudin, A. 2010. Peranan Faktorfaktor Individual dalam Mengembangkan Usaha: Studi kuantitatif pada wirausaha kecil di Salatiga. Jurnal Manajemen Bisnis. 3(2): 185-202.

17. Jones, C. \& Shao, B. 2011. The Net Generation and Digital Natives. A Literature Review Commissioned by the Higher Education Academy. Open University Review in United Kingdom. $1-56$.

18. Kaplan, R. S. \& Norton, D. P. 1996. The Balance Scorecard: Translating strategy into action. Harvard Business School Press, Amerika Serikat.

19. Kinggudu, M. N. (2002). Entrepreneurs and entrepreneuship in Africa: What is known and what needs to be done. Journal of Development Entrepreneurship, 7 (3), 239-258

20. Langen, F. \& Groenewegen, G. 2012. Critical Success Factors of the Survival of Start-Ups with a 
Radical Innovation. Journal of Applied Economics and Business Research. 2(3): 155-171.

21. Leutner, F., Ahmetoglu, G., Akhtar, R., \& Premuzic, T. C. 2014. The Relationship Between The Entrepreneurial Personality and The Big Five Personality Traits. Journal of Personality and Individual Differences. 58-63.

22. Nager, M., Nelsen, C., \& Nouyrigat, F. (2012). Startup Weekend: How to take a company from concept to creation in 54 hours. New Jersey: John Wiley \& Sons, Inc.

23. Nann, S., Krauss, J., Schober, M., Gloor, P. A., Fishbach, K., \& Fuhres, H. 2009. The Power of Alumni Networks - Success of Startup Companies Correlates With Online Social Network Structure of Its Founders. Journal MIT Sloan Research Paper. 1: 1-28.

24. Przepiorka, A. M. 2017. Psychological Determinants of Entrepreneurial Success and Life-Satisfaction. Journal from NCBI Online, 36: 304-315.

25. Rauch, A. \& Frese, M. 2007. Let's put the person back into entrepreneurship research: A metaanalysis on the relationship between business owners' personality traits, business creation, and success. European Journal of Work and Organizational Psychology. 16(4): 353 - 385.

26. Riyanti, B. P. D. 2003 Kewirausahaan dari Sudut Pandang Psikologi Kepribadian. Grasindo, Jakarta.

27. R., S., E., \& T. Pelaku Usaha Bisnis Startup Digital Aplikasi. Interview on 16-17 November 2016.

28. Seibert, S. E. \& Zhao, H. 2006. The Big Five Personality Dimensions and Entrepreneurial Status: A meta-analytical review. Journal of Applied Psychology. 91(2): 259-271.

29. Senge, P. M. 2010. The Fifth Discpline: The art and practice of the learning organization. Doubleday, New York.

30. Sivalingan, K. M. \& George, N. R. 2011. Next Generation Internet: Architectures and protocols. Cambridge University Press, New York.

31. Song, M., Podoynitsyna, K., Hand, V. D. B., Halman, J. I. M. 2008. Success Factors in New Ventures: A meta-analysis. The Journal of Product Innovation Management. 25(1): 7-27.

32. Sowole, O. E., Hogue, M. E., \& Adeyeye, O. P. (2018). Entrepreneurship: Psychological Factors Influencing Youth's Desire for Self-Sustenance in Mpumalanga. Academy of Entrepreneurship Journal. 24(2): 1-16.

33. Spector. P. E. 2012. Industrial and organizational psychology: Research and practice. (6th Ed.). John Wiley \& Sons, Singapore.

34. Startup Genome Report. 2012. A New Framework for Understanding Why Startup Succeed. Literature Report in Bekeley and Standford. 1-67.

35. Sugiyono. 2010. Metode Penelitian Kuantitatif, Kualitatif, dan R\&B. Alvabeta, Bandung.
36. Tagraf, H. \& Akin, E. 2009. Relations Between the Charateristics of Entrepreneurship and The Bussiness Owner: An analysis of SME'S in Konya. Serbian Journal of Management. 4(2): 239-257.

37. Ullah, H., Farooq, M. A., \& Ahmad, Z. M. 2012. A Study of Psychological and Non Psychological Factors of Owner Influencing Entrepreneurial Orientation: Evidence from Khyber PakhtunkhwaPakistan. Management Science and Engineering. 6(1): $44-55$.

38. York, J. L. \& Danes, J. E. 2014. Customer Development, Innovation, and Decision-Making Biases In The Lean Startup. Journal of Small Business Strategy. 24(2): 21-39.

39. Zaheer, H. 2015. How Do Innovative Digital StartUps Achieve Success? Perspectives of Australian Founders. Disertasi. Universitas Macquarie, Australia.

40. Zuliarni, S. 2014. Analisis Kreativitas dan Inovatif Pengusaha Industri Kreatif Sub Sektor Kerajinan di Pekanbaru. Jurnal Aplikasi Bisnis. 4(2): 110-123. 